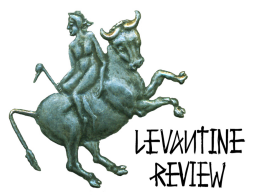

\title{
LEBANESE ARMENIANS; A DISTINCTIVE COMMUNITY IN THE ARMENIAN DIASPORA AND IN LEBANESE SOCIETY
}

\author{
Scott Abramson*
}

\begin{abstract}
Lebanon, for many Armenians, is referred to as "our second homeland" (yergort hayrenik), and it is scarcely difficult to see why. As nowhere else in the regional diaspora, Lebanon has offered its Armenian citizens-initially refugees-the economic freedom to achieve prosperity, the political freedom to pursue their interests, and the communal autonomy to preserve their identity. These freedoms and the efflorescence that they have enabled-to say nothing of Lebanon's singularity as the scene of unique Armenian ecclesiastical and cultural institutions - have made Lebanon a distinctive part of the Armenian diaspora. This study aims to demonstrate why this was-and continues to be-the case.
\end{abstract}

\section{INTRODUCTION}

In a series of migrations that began in Late Antiquity, Christians seeking security from persecution have sheltered in Lebanon. The Maronites inaugurated this tradition in the seventh century with their flight from Jacobite intolerance in Syria. Byzantine oppression further stimulated Maronite migration to Lebanon four centuries later, when Constantinople retook Syria from the Muslims and set about persecuting Christian dissenters from the Chalcedonian Creed. Next to flee to Lebanon were Melkite Greek Catholics in the seventeenth century. Having recently seceded from the Greek Orthodox rite to enter into communion with Rome, these Melkite Catholics were urged from Syria by the harassment of their former church. Their persecutors, the Greek Orthodox of Syria, were themselves targeted at intervals throughout the nineteenth century, largely by Sunni Muslims, and they too took sanctuary in Lebanon.

So when, in the wake of the First World War, thousands of Armenians arrived in Lebanon as refugees from what America's ambassador to Istanbul, Henry Morgenthau, called the Ottomans' "campaign of race extermination,"1 these newcomers had followed a welltrodden path taken by many beleaguered Christians before them. Nor was Lebanon even altogether new as a haven for Armenian refugees. In the last quarter of the seventeenth century Armenian Catholics escaping persecution of Apostolic Armenians in Anatolia, from

\footnotetext{
${ }^{1}$ Garin K. Hovannisian, Family of Shadows: A Century of Murder, Memory, and the Armenian American Dream (New York: Harper Collins, 2010), 97.
} 


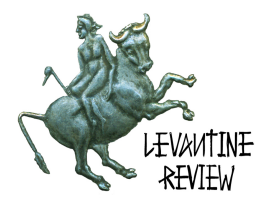

whose church they had defected, were received with alacrity in Lebanon by their fellow Catholic Maronites. ${ }^{2}$

But although Lebanese Armenians have been one more Christian people to avail themselves of Lebanon's hospitality, they have emerged as a distinctive community, not just in Lebanon's famously Balkanized polity, but in the Armenian diaspora too. It is these two singularities of the Lebanese Armenian condition that form the focus of this work. First, this essay inquires into the distinctive features of Armenian life in a country like no other in the Armenian diaspora. Frequent reference is often made in this section to others of the Armenian communities in the diaspora, particularly in the Middle East, in order to illustrate Lebanon's individuality. Lebanese Armenians are then contrasted with the farrago of other ethnic and religious communities in Lebanon. The design of this exercise is to underline exactly wherein Lebanese Armenians differ from the rest of the country's population. But before tackling the essay's two-part thesis, it is well to survey the antecedents of Lebanese Armenians.

\section{HISTORICAL OVERVIEW OF ARMENIAN SETTLEMENT IN LEBANON}

The Catholic Armenians who fled to Lebanon in the declining years of the seventeenth century may be credited with establishing the first enduring Armenian community in the land. The settlement of these Armenians was much aided by the generosity of the Maronite clan of the Khazens, the feudal lords of the district of Kisrawan north of Beirut. The Khazens and other Maronite notables contributed landholdings and money to help the Armenians establish themselves in Lebanon. ${ }^{3}$ The Maronites further acted on the Armenians' behalf in 1742, when they interceded with the Vatican to win Papal recognition for the patriarch of the Armenian Catholics. ${ }^{4}$ This ex cathedra gesture indeed marked the formal founding of the Armenian Catholic communion. ${ }^{5}$ Also in 1742, the Catholic Armenians, again with Maronite support, ${ }^{6}$ instituted a convent in Bzoummar in Kisrawan now acknowledged as the oldest extant Armenian monastery in Lebanon. ${ }^{7}$ Alongside it was built the patriarchal see for the entire Armenian Catholic Church.

\footnotetext{
${ }^{2}$ Avedis K. Sanjian, The Armenian Communities in Syria under Ottoman Dominion (Cambridge: Harvard University Press, 1965), 61.

${ }^{3}$ Ibid.

${ }^{4}$ Nicola Migliorino, Reconstructing Armenia in Lebanon and Syria: Ethno-Cultural Diversity and the State in the Aftermath of a Refugee Crisis (New York: Berghahn, 2008), 2008.

5 Ibid.

${ }^{6}$ Hratch Bedoyan, "The Social, Political, and Religious Structure of the Armenian Community in Lebanon," The Armenian Review 32, no. 2 (Summer 1979), 121.

${ }^{7}$ Nikola B. Schahgaldian, The Political Integration of an Immigrant Community into a Composite Society: The Armenians in Lebanon, 1920-1974 (Ph.D. Dissertation, Columbia University, 1979), 50.
} 


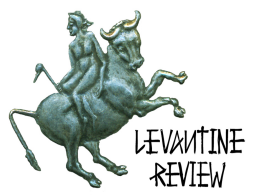

These Armenians integrated easily into the Lebanese milieu. Understanding themselves as Catholics more than Armenians, they aligned themselves with the Maronites almost entirely, intermarrying with them and even adopting the Levantine vernacular of the Maronites, or French, as their mother tongue in preference to Armenian. ${ }^{8}$ As the nineteenth century advanced, Protestant Armenians, converted either by American missionaries or recent Armenian converts, appeared in Lebanon alongside their Catholic kinsmen. This proliferation of Armenian Protestants notwithstanding, the mass of Lebanon's Armenians remained Catholic until the fin-de-siècle. ${ }^{9}$

Around 1880 there began an influx of Apostolic Armenians into Lebanon that would in due course strip the Armenian Catholics of their preponderance. Enterprising Armenians came to Beirut to establish firms in the city that was the principal entrepot in the region, while Armenian students came to pursue their studies in Lebanon's choice institutions of higher learning, the finest in the Ottoman Empire. ${ }^{10}$ But if these settled in Lebanon by choice, the Armenians who came in the 1890s did so by necessity. In 1894, the Ottoman government in the person of Sultan Abdul Hamid II entered upon a prelude to the genocide that the Young Turks would prosecute two decades later. In the ensuing three years, the Porte mounted a series of massacres against Armenians in Anatolia and the Armenian Highlands that claimed perhaps 200,000 victims and created tens of thousands of refugees. To the Armenians fleeing the carnage, Lebanon beckoned as a particularly appealing destination, not least because half the country had been a European-protected autonomous province, the Mount-Lebanon Mutasarrafiya since 1861, and was thus secure from the sultan's brutalities. The existing, largely Catholic Armenian population, together with the Maronite Church, saw after these anguished newcomers, many of whom were orphans, and afforded shelter and money. ${ }^{11}$

That these Armenian refugees were Apostolic, rather than Catholic, was scarcely the only difference that marked them off from the veteran Armenian community. Whereas the Catholic Armenians eschewed particularism and affiliated with the Maronites, the Apostolics shared a strong communalist sentiment. Particularly eloquent of this difference was the circumstance that the Catholic Armenians failed to establish any schools expressly for their community, ${ }^{12}$ save for the monastery at Bzoummar, whereas the Apostolic newcomers quickly set themselves to founding not only schools, but also several social and philanthropic organizations, all of a specifically Armenian character. ${ }^{13}$ The political corollary of the Apostolics' particularist ethos, Armenian nationalism, found concrete

${ }^{8}$ Schahgaldian, Political Integration, 52.

${ }_{9}^{9}$ Nikola B. Schahgaldian, "Ethnicity and Political Development in the Lebanese Armenian Community, 1925-1979," The Armenian Review 36, no. 1 (Spring 1983), 47.

10 Sanjian, 63-64.

11 Schahgaldian, Political Integration, 53.

12 Schahgaldian, Political Integration, 52.

13 Sanjian, 66. 


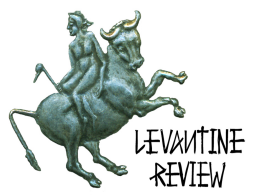

expression in Lebanon at the turn of the century with the establishment of the Lebanese branch of the Armenian nationalist Dashnak Party in Beirut. ${ }^{14}$ Thus had developed in Lebanon a burgeoning and comfortable, if still small, Armenian community numbering a few thousand on the eve of the First World War.

If the massacres of Sultan Abdul Hamid II had produced a trickle of Armenian refugees into Lebanon, the Armenian Genocide generated a flood. Thousands of moribund Armenians deported from their homeland dragged their weary bodies along a via dolorosa whose terminus fell in Lebanon. But far from finding the sanctuary there that their predecessors had, these refugees were greeted by a country in a ghastly plight. In 1915, amid the unfolding of the Armenian Genocide, Jamal Pasha, one of the triumvirs in the Young Turk regime and the commander of the Ottoman Fourth Army, abolished the autonomy of the Mutasarrafiya and levied a blockade against Lebanon. The resulting famine was aggravated further by the dislocation of the economy and a visitation of locusts. By war's end, these devastations had combined to bereave Mount Lebanon of one-third of its population. Indeed, so grievous was Lebanon's lot during the First World War that Phillip Hitti was moved to assert that "it is doubtful whether any other Ottoman province suffered as much."15 It was against this backdrop of anguish and privation that some of the Armenians who had escaped the fate of so many of their kinsmen began to arrive in Lebanon. Thousands of the incoming survivors were interned in tents and, many of them being diseased, quarantined. ${ }^{16}$ Larger still was the deluge of Armenians who poured into Lebanon in the immediate postwar years. Particular impetus was given to their movement into the country in 1922, after the French, who had occupied Cilicia since 1918, ceded the territory to the Kemalists in exchange for Turkish acquiescence in French control of Syria. Without French aegis and fearing redoubled persecution from the Turks, the Cilician Armenians fled en masse, many of them to Lebanon. In the ensuing years, the Cilician Armenians freshly settled in Lebanon would be joined by refugees from historic Armenia. These accretions had so augmented the Lebanese Armenian population that by 1926 , theirs was a community now overwhelmingly composed of refugees. There followed two further infusions of refugees that swelled the community still further. In 1929 and 1930, part of the vestige of the pre-war Armenian population in Anatolia quit Turkey under threats and intimidation and settled in Lebanon, ${ }^{17}$ and in 1939, when the French yielded the Sanjak of Alexandretta to the Turks, many of the province's Armenians, rather like their Cilician counterparts in 1922, fled to Lebanon.

${ }^{14}$ Schahgaldian, The Political Integration, 54.

15 Phillip K. Hitti Lebanon in History: From the Earliest Times to the Present (London: Macmillan, 1967), 484.

${ }^{16}$ Hilmar Kaiser, "The Armenians in Lebanon during the Armenian Genocide," in Armenians of Lebanon: From Past Princesses and Refugees to Present-Day Community, ed. Aida Boudjikanian (Beirut: Haigazian University \& Armenian Heritage Press, 2009), 37. 17 Migliorino, 31. 


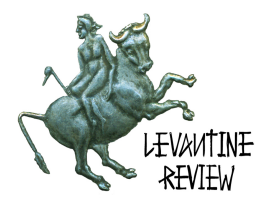

In the two decades that followed the First World War, the Armenian refugees struck roots in the localities that would in due course be Lebanon's main Armenian enclaves. The refugees, however, understood their residence in Lebanon as temporary, as a kind of sojourn pending their restoration to the Armenian homeland. They nevertheless proceeded as if they were in Lebanon to stay. The first imperative was to find quarters that were more agreeable than the deplorable canvas tents in the Armenian favelas in Beirut (particularly Karantina) and its surrounds. In this, the Armenian refugees benefitted from the patronage of the Armenian Catholic Church, ${ }^{18}$ the Lebanese authorities, the League of Nations, and various Armenian relief organizations. ${ }^{19}$ But the refugees themselves were the principal agents of their own acclimation in Lebanon. The Armenians from Cilicia, who accounted for the great bulk of the refugees, coalesced into small associations (hayrenaktsakans) whose members all originated in the same locality in Turkey. The hayrenaktsakans would aggregate their money and purchase land, often at reduced rates, from obliging Christian landowners in Beirut. ${ }^{20}$ Each acquisition was then divided into plots that were parceled out to individual proprietors. ${ }^{21}$ Thus did the Armenian population centers in Beirut, most famously Bourj Hammoud, emerge in the twenties and thirties. Complementing the labors of the hayrenaktsakans was the Central Relief Committee (established in 1926), which aided in the construction of new neighborhoods for the refugees. ${ }^{22}$

\section{THE CONSOLIDATION AND INTEGRATION OF THE LEBANESE ARMENIAN COMMUNITY}

The Lebanese Armenian community's metamorphosis in the decades that followed the First World War was as swift as it was thoroughgoing. In the early 1920s, Lebanese Armenians were largely a community of refugees, immiserated and detached from Lebanese society. By the departure of French troops from the Levant in 1946 Armenians were no longer an alien element in Lebanon, ${ }^{23}$ and when the First Lebanese Civil War broke out twelve years later, they had become "a fully integrated national minority group." 24 The change of the Armenians' circumstances was paralleled by a concomitant change in their conception of their stay in Lebanon. Whereas most of Lebanon's Armenians had initially

18 Ibid., 51.

19 Vahe Tachjian, "The Permanent Settlement of Armenian Refugees in Lebanon in the Years 1920 and 1930," in Armenians of Lebanon: From Past Princesses and Refugees to Present-Day Community, ed. Aida Boudjikanian (Beirut: Haigazian University \& Armenian Heritage Press, 2009), 75.

20 Meguerditch Bouldoukian, “Armenian Business in Lebanon,” The Armenian Review 32, no. 2 (Summer 1979), 131.

${ }^{21}$ Bouldoukian, 131.

22 Tachjian, 75.

${ }^{23}$ Migliorino, 89.

24 Tsolin Nalbantian, Fashioning Armenians in Lebanon, 1946-1958 (Ph.D. Dissertation, Columbia University, 2011), 303. 


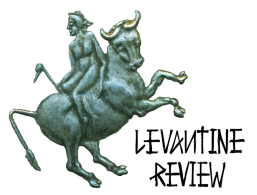

understood themselves as "a nation in temporary exile,"25 they would thirty years later speak of Lebanon as their fatherland. ${ }^{26}$

The Treaty of Lausanne in 1923 was the first jolt that sobered the refugees to the prospect that their stay in Lebanon might not be as temporary as they had supposed. Three years earlier, the triumphant Allied powers and the Ottoman Empire concluded the Treaty of Sevres, which stipulated, inter alia, the creation of an independent Armenia coextensive with much of historic Armenia in eastern Anatolia. In 1923, however, the Allies acceded to the revanchism of the new Turkish Republic and signed with the latter a superseding document, the Treaty of Lausanne. This "final blow to Armenia," as Peter Balakian put it,27 meant that the official state of the Armenian people was to remain no larger than Soviet Armenia, a mere rump of the Armenian homeland.

The Treaty of Lausanne not only confounded the hope of the Armenian refugees who aspired to repatriation, it changed their status in their host countries too. Among its provisions was the requirement that refugees from Anatolia now living in former Ottoman territories be entitled to citizenship. For the French mandatory authorities in Lebanon and their Maronite protégés, for whom augmenting Lebanon's Christian sector was a major desideratum, this clause was providential. So in 1924, in the teeth of opposition from Lebanon's Sunni Muslims, Lebanese Armenians were naturalized en masse.

Two further happenings in the years that followed contributed to Lebanon's importance in the Armenian diaspora and to the acclimation of Armenians in the country. First, in 1928, the headquarters of the Armenian Catholic Church, having moved to Constantinople in the nineteenth century, returned to Lebanon. Lebanon was not only the cradle of the Armenian Catholic Church; it was now also host to the Armenian Catholics' largest community. ${ }^{28}$ The second pivotal event around this time, likewise ecclesiastical, was the relocation to Lebanon of the Catholicosate of Cilicia (the see of one of the two preeminent pontiffs, or "catholicoi," in the Armenian Apostolic Church). From its founding in the High Middle Ages through 1921, the Catholicosate of Cilicia had been in Sis (Kozan in modern Turkey), but in 1930, the see moved to Antelias north of Beirut, where it has remained ever since. When it took up quarters at Antelias, the Catholicosate of Cilicia exercised jurisdiction over all the Apostolic Armenians of Lebanon, Syria, Jerusalem, and Cyprus. Later, its writ would extend to still more dioceses. That so venerable and influential an institution was now based in Lebanon transformed the country into a spiritual center for many Armenians of the diaspora.

25 Schahgaldian, Political Integration, 1.

26 Schahgaldian, Political Integration, 227.

27 Peter Balakian, The Burning Tigris: The Armenian Genocide and America's Response (New York: HarperCollins, 2003), 369.

${ }^{28}$ Rouben Paul Adalian, Historical Dictionary of Armenia (Lanham: Scarecrow Press, 2010), 232. 


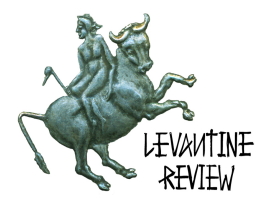

The move to Lebanon of the Armenian Catholic Church and the Catholicosate of Cilicia coincided with the earliest stage of Armenian political participation in Lebanon. Armenians initially held aloof from Lebanese politics, ${ }^{29}$ feeling as they did that their political resources ought instead to be placed undividedly at the service of the greater Armenian cause. The reverses of the early twenties, however - the Soviet subjugation of Armenia and the accession of Armenian lands to Turkey under the Treaty of Lausanne-made political detachment less tenable. The community accordingly abandoned this posture, and, in 1925, the Armenians commenced their involvement in Lebanese affairs by voting for the renewal of Lebanon's Representative Council (an elected mostly advisory body subordinate to the French High Commission)..$^{30}$ In 1929, Abdullah Ishaq, became the first Armenian parliamentarian to serve in Lebanon's Chamber of Deputies. Ishaq, though, was Catholic and thus unrepresentative of the overwhelmingly Apostolic Armenian community. Moreover, he served not as an official "Armenian" representative but as a representative of "minorities." ${ }^{1} 1$ Far more consequential a year in the political career of the Lebanese Armenians was 1934. It was then that one seat in the Lebanese parliament was earmarked for an Apostolic Armenian and that the first official Armenian deputy was elected. ${ }^{32} \mathrm{An}$ official Armenian representative has been returned in every parliamentary election since.

Although the first two Armenian parliamentarians elected to the Chamber of Deputies were independents, Armenian political parties in Lebanon, most especially Dashnak, quickly assumed leadership of the community. Since the thirties, three nationalist parties have bestridden the Armenian political scene in Lebanon: the anti-Soviet socialist Dashnak, the fellow-traveling Hunchak, and the elite liberal capitalist Ramkavar. Their programmatic positions notwithstanding, all three outfits have time and again shown themselves more pragmatic than dogmatic. Exigencies prevailed over ideologies, for example, in integrating Hunchak and Ramkavar into alliance, in impelling the Dashnak's retreat from revolutionary socialism, and in sealing the Dashnak's long entente with Lebanon's right-wing parties.

In contrast to Lebanon's other sects, political parties among the Armenians were the community's natural leaders. Inasmuch as the two other Armenian elements that exercised the most leverage-namely, the established mercantile elite and the clergy-were not at all engagé, political leadership of the community naturally fell to the parties. Of the three political parties, Dashnak gained the most successes. Thanks to its network of schools and cultural societies - to say nothing of its hard-won image as the standard-bearer of Armenian nationalism - the party gradually became ascendant in Lebanon. Its primacy was consolidated further by the departure to Soviet Armenia of many Hunchak and

${ }^{29}$ Migliorino, 52.

${ }^{30}$ Ibid., 57.

${ }^{31}$ Schahgaldian, Political Integration, 178.

${ }^{32}$ Schahgaldian, Political Integration, 178. 


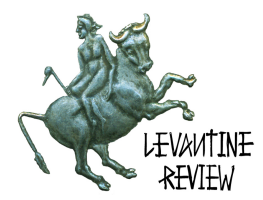

Ramkavar partisans in the forties, ${ }^{33}$ and most especially, by the investiture of a Dashnak ally, Zareh I, as Catholicos of the Cilician see in 1956. From the late fifties until the nineties, the party provided the bulk of Lebanese Armenian parliamentarians.

To be sure, the participation of Armenian parties and deputies in Lebanon's political order conferred many obvious benefits, but it posed a forbidding challenge too, that of what might be described as "triangulation." In the Lebanese context, triangulation meant that the Armenians could pursue their interests through the organs of the political system, but, in doing so, they had to take great care not to alienate other of the country's many sects. This was a particularly treacherous proposition in Lebanon, "where any position anyone took automatically generated its own antithesis, between the rival sects internally, and between the rival states, to which the sects were invariably linked, regionally and internationally." 34 The Armenians managed this balancing act with remarkable finesse. They generally refrained from espousing political positions except those that impinged directly on their community. ${ }^{35}$ On the fitful occasions when the Armenians did pick sides, the hazards were often mitigated by a split among the Armenians themselves, as during the First Lebanese Civil War in 1958, when Dashnak supported the faction of President Camille Chamoun, while Hunchak and Ramkavar supported the Arab nationalist opposition. Consensus positions, from which few in the Lebanese body politic dissented, were likewise safe. Perhaps the only such position in Lebanon during the twilight of the French mandate was independence from France. Although the Armenians were rather favorably disposed to the French mandate, at least until the French relinquished Alexandretta to Turkey in 1939, all three Armenian political parties endorsed independence from France.

Just as Armenians integrated into the Lebanese political system, so they integrated into the Lebanese economy. The Armenians have prospered as much in the Lebanese economy as they have contributed to it. Perhaps with some measure of exaggeration, one observer noted in 1975, until which year Lebanon had seen remarkable economic growth, that "Armenians form approximately eight percent of the Lebanese population, while their contribution to the national income of Lebanon is fifteen percent." 36 No less impressive is the datum that the per capita income of Armenians was forty percent more than the Lebanese national average. ${ }^{37}$ Armenians thrived in Lebanon as artisans, merchants, and professionals of every variety, winning a reputation in Lebanese society for their industry and honesty. ${ }^{38}$ Government employment held little appeal for them, so much so that

\footnotetext{
33 Nalbantian, 115.

34 David Hirst, Beware of Small States: Lebanon, Battleground of the Middle East (New York: Nation, 2010), 27.

35 Migliorino observes that the Armenians who joined the Lebanese Communist Party and the Kataeb were anomalies in that they staked out political positions unapologetically.

36 Bouldoukian, 132.

37 Ibid.

38 Migliorino, 133.
} 


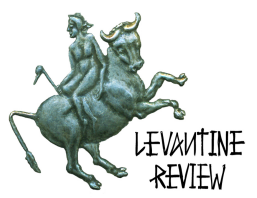

Armenians scarcely reached their quotas in Lebanon's confessionally divided public sector. ${ }^{39}$

Such was the Armenians' mobility that they had gone from being pauperized refugees in the twenties to one of Lebanon's most prosperous communities decades later. ${ }^{40}$ This efflorescence was doubtless the result of a synergy between the acumen of the Armenians and the liberality of the Lebanese economy. With its laissez-faire market and prizing of commerce, Lebanon was especially conducive to the Armenians' proverbial talents in business. Robert Hewsen has even maintained that "Lebanon enabled the Armenians to flourish as they had not done anywhere since the great days of Ottoman Constantinople." 41 As a mercantile people, the Armenians felt much at home in the "merchant republic."

Along with political and economic integration, social integration came too. Lebanon's Christians generally respected the Armenians for contributing their talents to the economy and their numbers to the Christian sector, ${ }^{42}$ the latter being of existential importance to most Lebanese Christians before being rendered politically déclassé by the Ta'if Accord of 1989. Though not terribly common, intermarriage between Armenians and Lebanese Christians did happen and the frequency of such unions increased over time. ${ }^{43}$ Muslims, for their part, though initially averse to the Armenian refugees and their naturalization (largely because of its demographic implications,) gradually thawed to the Armenians. ${ }^{44}$ The fondness was reciprocal. Armenians likewise felt affinity for their fellow Christian and Muslim citizens. ${ }^{45}$ So when the Lebanese statesman Raymond Eddé spoke of "Armenians of the Lebanese family," 46 he had given utterance to a sentiment that the Armenians themselves had come to harbor.

\section{REPRESENTATION AND AUTONOMY}

\footnotetext{
${ }^{39}$ Migliorino, 133.

${ }^{40}$ Bouldoukian, 132.

${ }^{41}$ Robert H. Hewsen, Armenia: A Historical Atlas (Chicago: University of Chicago Press, 2001), 268.

${ }^{42}$ Aghop H. Der-Karabetian, "Image and Self-Image of Armenians in Lebanon: A Psychosocial Perspective," in The Armenian Image in History and Literature, ed. Richard G. Hovannisian (Malibu: Undena, 1981), 242.

${ }^{43}$ Aghop Der-Karabetian and Emma Oshagan, "Ethnic Orientation of Armenians in Lebanon," in The Armenian Review 30, no. 2 (Summer 1977), 164.

${ }^{44}$ Bedoyan, 120.

${ }^{45}$ Aghop Der-Karabetian and Emma Oshagan, "Ethnic Orientation of Armenians in Lebanon," 164.

46 Nalbantian, 295.
} 


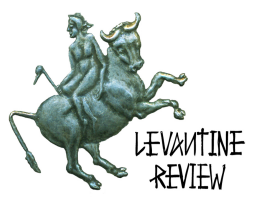

No other country in the Armenian diaspora has accorded Armenians the official political representation and communal autonomy that Lebanon has. ${ }^{47}$ Lebanon's confessional political order, whose vintage dates from 1845, has served the community especially well. Since the Armenians first gained a seat in the Chamber of Deputies in 1934, their political representation has only broadened. In 1937, they won a second mandate, ${ }^{48}$ and whenever the number of seats in the Chamber of Deputies subsequently increased (as happened in 1951, 1960, and 1989), the Armenians correspondingly gained another on each occasion. At present, the Armenians boast six seats (five for Apostolics and one for a Catholic) in the 128-member legislature. They are also guaranteed a ministerial portfolio. Before the Second Lebanese Civil War (1975-1990), one cabinet position was allotted to the Armenians, but the Ta'if Accord of 1989, which codified the new postbellum political order, prescribes that Armenians receive a second portfolio when there are thirty or more members in a cabinet. ${ }^{49}$ While all but one of the mandates in the Chamber of Deputies is designated for Apostolics, Catholic Armenians have held their single seat in the Lebanese parliament since the French mandate. Protestant Armenians, the largest single Protestant ethnic group in Lebanon, ${ }^{50}$ are not officially entitled to their own seat, but their plurality has often won them this post.

In the Armenian diaspora, Lebanon is unique in being the only country that guarantees its Armenian community both parliamentary and ministerial representation. ${ }^{51}$ In the three other countries in the Middle East where Armenians live in sizeable numbers-Turkey, Iran, and Syria - the case is vastly different. Inasmuch as Turkey is a state that imposes "strict civic nationalism which insists on the full 'Turkishness,' cultural and linguistic as well as political, of all of the republic's citizens," Armenians are denied political representation qua Armenians, but they are permitted to serve in the Turkish legislature as nonsectarian representatives of electoral districts, not as Armenian advocates. In Iran, in contrast, Armenians have enjoyed institutional political representation (qua Armenians) since Iran's First Majlis convened in 1906. Iranian Armenians, moreover, are the only one of Iran's four officially recognized minorities to whom two parliamentary seats (as opposed to one) are allocated, a distinction they have boasted since the Fifth Majlis (1925-1927). ${ }^{52}$ But while Iranian Armenians are ostensibly represented in the Majlis, their political

47 Nalbantian, 56.

48 George H. Aynilian, “Armenian Deputies in Lebanon (1929-2009)," Keghart, (http://www.keghart.com/Aynilian-Deputies).

49 Roupen Avsharian, "The Ta'ef Agreement and the Lebanese Armenians," in Armenians of Lebanon: From Past Princesses and Refugees to Present-Day Community, ed. Aida Boudjikanian (Beirut: Haigazian University \& Armenian Heritage Press, 2009), 404. ${ }^{50}$ Harry Corbin, Kathryn Griffith, and Assad Rahhal, "Observations on the Armenians in Lebanon Made in 1970-73,” The Armenian Review 28, no. 4 (Winter 1975), 396.

51 Nalbantian, 56.

52 Elie Sanasarian, Religious Minorities in Iran (Cambridge: Cambridge University Press, 2000), 176. 


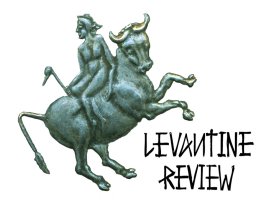

leverage-first, under the Pahlavi autocracies, then, under the Islamic theocracy-has been more Potemkin than actual. In the First Majlis of 1906, for example, the Armenian delegate declined to take up his appointment when persecution from the Muslim clergy threatened, ${ }^{53}$ and the Armenian parliamentarians who later did serve were mere figureheads under the Pahlavis' authoritarian regimes. ${ }^{54}$ Armenians and other non-Muslim minorities, moreover, were ineligible for ministerial posts or conspicuous high political offices. ${ }^{55}$ These strictures have only tightened under the Islamic Republic. As in Iran, in Syria scant power is vested in Armenian parliamentarians. True, Armenians have had a seat in the Syria legislature since the Chamber of Deputies was constituted by the French mandatory regime in 1928 (except between 1963 and 1971), but the chronic instability of Syria in the two decades after its independence and the despotic rule of the Assad dynasty since 1970 have made the Syrian parliament a completely nugatory body. Moreover, the "elections" of Armenian incumbents in the Syrian parliament have reflected more the preference of the Baathist regime than the will of the Armenian constituency. ${ }^{56}$ In consequence, the service of the Armenian delegates in the Assads' rubber-stamp "People's Council," (the re-baptized Chamber of Deputies) has availed Syrian Armenians little.

The measure of communal autonomy Lebanese Armenians enjoy is likewise anomalous in the Armenian diaspora. The millet dispensation of the Ottoman Empire, which permitted its main religious groups the disposition of their own affairs, lives on in the Lebanese Republic. Fragile though it may seem in the endemic instability of the Middle East, the millet system has proved quite durable in Lebanon. There indeed exists in the country peculiar circumstances that have all but ensured the continuation of this autonomous order. The diversity and fragmentation of Lebanon's population (ideological as well as ethnic and religious) have precluded any one sect from gaining absolute power and, failing that, from using such power to impose itself on other sects. Further militating against any disturbance to the status quo of communal autonomy has been the perennial weakness of Lebanon's central government. Though the Lebanese state's weakness has at times been its Achilles heel, Lebanese Armenians cherish the latitude it and the institutionalization of the millet system provide. Lebanese Armenians administer their own private schools (in which the curriculum is taught in Armenian) and Armenian clergy, representing all three denominations, regulate the personal status of their communicants in their own religious courts-all without government intrusion. So congenial has the Lebanese system been to the Armenians' self-sufficient temper, Robert Hewsen has concluded that "nowhere in the Middle East did the concept of the millet system take such hold and nowhere in the area did

53 Janet Afary, The Iranian Constitutional Revolution, 1906-1911 (New York: Columbia University Press, 1996), 70.

${ }^{54}$ Sanasarian, 39.

${ }^{55}$ Sanasarian, 39.

${ }^{56}$ Nikola Migliorino, "Kulna Suriyyin? The Armenian Community and the State in Contemporary Syria," Revue des Mondes Musulmans et de la Méditerranée 115-116 (December 2006), 


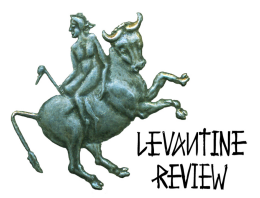

the Armenians flourish so well under it as in the Republic of Lebanon." 57 Inasmuch as Lebanon's communal autonomy favors hayabahbanum (the preservation of the Armenian people and their identity), the specter of assimilation, whether voluntary as in the United States and France or pressured as in Turkey, does not threaten the Lebanese Armenians in equal measure. Nor has Lebanon burdened its Armenians with an identity crisis. ${ }^{58}$ Armenians see not a conflict between their Lebanese and Armenian identities but a complementarity. Thus did one of the community's members remark that Lebanon empowers its Armenians to feel "100\% Armenian and 100\% Lebanese at the same time."59

Contrarily, the responses to expressions of Armenian particularism in Turkey, Iran, and Syria have oscillated between sufferance and repression. Turkey's vestigial post-Genocide Armenian community has taken care to be discreet in asserting its identity. As citizens of a state that enforces, sometimes violently, the nationalism of Ataturk, Turkish Armenians have quite often adopted Turkish names and avoided speaking Armenian in the interest of self-preservation. Despite this self-effacement, they have been regularly oppressed by state interference and obscurantism. The Armenian patriarchate and its parochial schools have been subject to arbitrary restrictions, and patriarchal elections have been marred by government intervention. ${ }^{60}$ In respect to communal autonomy, the lot of Iranian Armenians has been better, if still checkered. Under Reza Khan, Iranian Armenians benefitted from some measure of communal autonomy, but it was often infringed by the Shah, as in 193839, when he shuttered Armenian schools. Under Mohammed Reza Pahlavi, the internal autonomy of the Armenians was fully restored, though as noted, the Armenians remained barred, as non-Muslims, from certain political offices. ${ }^{61}$ Iranian Armenians' autonomy has been severely circumscribed in the Islamic Republic, Armenian schools being one of the principal targets of government interference. In 1981, the regime attempted an outright ban on the teaching of the Armenian language in Armenian schools, enjoining that all instruction (even in religion) be in Persian. ${ }^{62}$ The Armenians remonstrated, with the result that many Armenian schools were closed. The government then conceded a sop allowing the Armenians to conduct classes in their language for two hours a week. ${ }^{63}$ Despite its

\footnotetext{
57 Hewsen, 268.

58 See Harry Corbin, Kathryn Griffith, and Assad Rahhal, "Observations on the Armenians in Lebanon Made in 1970-73," The Armenian Review 28, no. 4 (Winter 1975), 391-409. ${ }^{59}$ Nikola Migliorino, "The Lebanese System and Armenian Cultural Diversity between Yesterday, Today, and Tomorrow: Opportunities and Limits," in Armenians of Lebanon: From Past Princesses and Refugees to Present-Day Community, ed. Aida Boudjikanian (Beirut: Haigazian University \& Armenian Heritage Press, 2009), 480.

${ }^{60}$ R. Hrair Dekmejian, "The Armenian Diaspora," in Armenian People from Ancient to Modern Times 2 (New York: St. Martin's Press, 2004), 423.

61 Sanasarian, 39.

62 Massoume Price, Iran's Diverse Peoples: A Reference Sourcebook (Santa Barbara: ABC-Clio, 2005), 314.

63 Price, 314.
} 


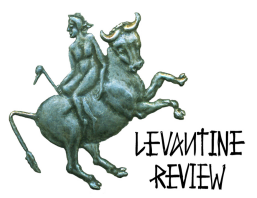

stringency, this decree has not been applied uniformly throughout Iran, and it is not unknown for indulgent government officials to condone instruction in Armenian beyond the official two-hour-a-week maximum. ${ }^{64}$

Syrian Armenians, for their part, have experienced many vicissitudes in upholding their community's autonomy. Whereas the French mandatory authorities were content to permit the Armenians considerable autonomy, certain of the Arab nationalist leaders of independent Syria have not been similarly permissive. Between 1949 and 1970, wherein there occurred ten successful coups and many more abortive ones, ${ }^{65}$ the Syrian Armenian community was at the mercy of any given ruler's caprice. Adib Shishakli, Syria's chauvinistic president in the early fifties, outlawed all political parties and banned communalist associations (including relief organizations). ${ }^{66}$ After Shishakli's fall, restrictive measures of this kind relaxed, but they recrudesced between 1958 and 1961, during the Syrian-Egyptian experiment in unity known as the United Arab Republic (UAR). As the UAR's omnipotent leader, Gamal Abdul Nasser ${ }^{67}$ presided over a virtual police state in which all political parties (except for his own National Union Party) were dissolved. The Dashnak chapter in Syria had stirred the suspicions of the regime on account of the party's pro-Western orientation, with the result that several party apparatchiks were arrested and even tortured to death. ${ }^{68}$ Other Dashnak activists made for Lebanon, there to enjoy the benefits of a largely free and thriving civil society. ${ }^{69} \mathrm{~A}$ brief respite from repression was afforded by the breakup of the UAR and the restoration of Syrian sovereignty. After the Baathist coup, however, Armenian autonomy was threatened anew. In 1965, the Baathist junta ordered that Armenians denominate their schools with Arabic, not Armenian, names. ${ }^{70}$ So too were Syrian Armenians pressured to either adopt Arabic surnames outright, or to adapt their Armenian surnames to Arabic phonology and morphology. The next Syrian regime, that of the radical faction of Baathists, went further, practically restricting all expressions of Armenian individuality and particularism. The Armenians' communal organizations, media, and political activities were accordingly curbed. Armenian private schools, moreover, were now constrained to teach a curriculum devised by the government, one in which non-Arab subjects hardly figured at all. ${ }^{71}$

On this vexing question of autonomy, a sustainable accommodation was at last reached between Armenians and the Syrian regime in the person of Hafez al-Assad, who installed

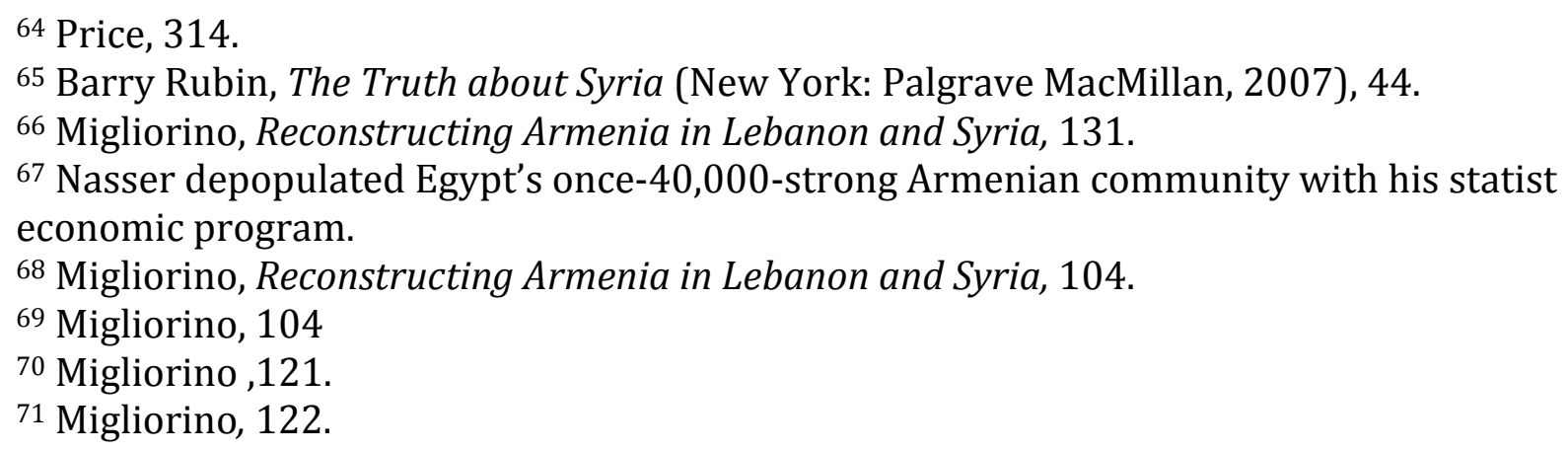




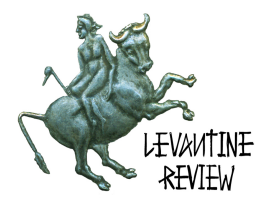

himself in power in 1970 in the last in a long concatenation of coups. This tacit understanding was based on a quid pro quo whereby a modest measure of autonomy would be restored and maintained for the Armenians in exchange for their support or at least acceptance of Assad's minoritarian regime. ${ }^{72}$ For the more than forty years of the Assad clan's rule, this agreement has held, and the Armenians of Syria have maintained their limited autonomy at the sufferance of the regime.

Whereas the Armenians elsewhere in the Middle East have chaffed under the impositions of Turkification, Islamization, and Arabization, the Lebanese Armenian experience stands in sharp relief. The Armenians of Lebanon, as nowhere else in the region, have been free to attend their own schools, to speak and teach their language, to maintain their communal organizations, to profess their religions, and to bring out their own publications-all without hindrance. Thus did Atzag, the Dashnak's organ in Lebanon, editorialize in 1958 that "there is not one other country where the life of the Armenian is this advanced and this progressive as here...no other place where our national life is organized so well, and so efficiently, as here."73

\section{THE DISTINCTIVENESS OF LEBANON IN THE ARMENIAN DIASPORA}

"Nobody can ever deny that Lebanon is the cultural and educational center of the Diaspora. It has become a kind of modern-era Yerkir-homeland." 74 So proclaimed the Lebanese Armenian poet Mushegh Ishkan in an article titled "Lebanon: The Central Fortress of Culture in the Diaspora." Protestations of this kind from Armenian eminences have been commonplace, particularly before the Second Lebanese Civil War. No less a personage than Vazgen I, the Catholicos of the Armenian Apostolic Church from 1955 to 1994, once pronounced Lebanon the seat of "our brightest community."75

\section{Culture}

One of the distinctive features that gave the Lebanese Armenian community this centrality in the diaspora was its cultural endeavor. Lebanon was indeed said to have conduced to hayabahbanum more than anywhere else in the Armenian diaspora. ${ }^{76}$ As early as the twenties, the fecundity of Lebanese Armenian cultural enterprise was already in evidence. In 1924, Nor Piunik, the first Armenian newspaper in an Arab-defined country went to

\footnotetext{
72 Migliorino, 156-157.

73 Nalbantian, 298.

74 Khatchik Der Ghoukassian, "Lebanon in My Mind. The Civil War and the Centrality of the Lebanese Armenian Community in the Making of the Armenia Diaspora Nationalism," in Armenians of Lebanon: From Past Princesses and Refugees to Present-Day Community, ed. Aida Boudjikanian (Beirut: Haigazian University \& Armenian Heritage Press, 2009), 422.

75 Ghoukassian, 422

76 Ghoukassian, 415.
} 


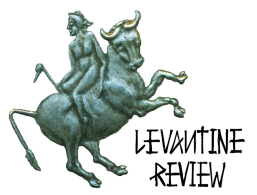

press, ${ }^{77}$ and by 1944, fifty-seven Armenian publications were being issued in Lebanon. ${ }^{78}$ Lebanon's three main political parties each brought out their own dailies and the country's Armenian churches, their own recurring publications. Soon, Lebanon became in the Armenian diaspora what it had always been in the Middle East at large: the premier publishing capital of a multinational people. As the freest country in the Arab sphere, and one in which censorship was comparatively limited, Lebanon was fated for this role, its Armenian intellectual harvest a consequence of this distinction. The Armenian cultural efflorescence continued to the point that the eve of the Second Lebanese Civil War found five Armenian dailies, six weeklies, and close to fifty other periodicals in Beirut alone. ${ }^{79}$ And for all the ravages the war exacted on Lebanese civil society, Lebanon remains the publishing capital of the Armenian diaspora.

The Lebanese Armenian intelligentsia was one of the great sinews of the Armenian literary and journalistic scene in Lebanon. But as the Armenian literati in Lebanon flourished in a free society, Armenian intellectuals in Syria languished under the government's obscurantism. Consequently, a huge Syrian Armenian brain drain flowed into Lebanon, further fructifying the country's intelligentsia. In the years immediately following Syria's independence from France, an entire generation of Armenian intellectuals from Aleppo removed themselves to Beirut. ${ }^{80}$ But it was not just Syria from which Armenian beauxesprits fled to Beirut; Armenian intellectuals fleeing Soviet Armenia and repressive regimes in the Middle East came to Lebanon to avail themselves of its freedom. Among these personalities were Simon Vratzian, Nikol Aghbalian, Levon Shant from Soviet Armenia and Antranik Zaroukian and Vahe Vahian from Syria.

\section{Education}

In the field of education, Lebanon was also distinctive in the Armenian diaspora. Since the nineteenth century, Armenians have been well served by Lebanon's educational institutions. Armenians from Lebanon's pre-Genocide community and from elsewhere in the region began attending Lebanon's Syrian Protestant College (later renamed the American University of Beirut) and Université Saint-Joseph no sooner than the schools had been founded in the latter part of the nineteenth century. ${ }^{81}$ After the genocide inflated it far beyond what it had previously numbered, Lebanon's Armenian community began opening its own schools, first, in the refugee camps and, later, in more congenial surrounds. One of the latter was a secondary school called Jemaran ${ }^{82}$ that was founded by Dashnak activist and educator Nikol Aghbalian. Opened in Beirut in 1930, this lyceum became, according to

\footnotetext{
77 Schahgaldian, Political Integration, 154.

78 Migliorino, Reconstructing Armenia in Lebanon and Syria, 69.

${ }^{79}$ Schahgaldian, Political Integration, 2-3.

80 Migliorino, Reconstructing Armenia in Lebanon and Syria, 123.

81 Sanjian, 66.

82 The school's name was later changed to the Neshan Palanjian Academy.
} 


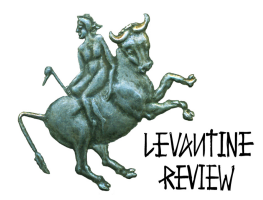

Rouben Paul Adalian, "the premier educational institution in the Armenian diaspora." 83 The school gained particular cachet with the appointment as principal of Simon Vratzian, the last prime minister of Armenia before the country was communized. By 1948, there had emerged fifty-nine Armenian schools in Lebanon serving nearly eleven thousand pupils. ${ }^{84}$ The Lebanese Armenian community also addressed itself to higher education. In 1955, two Protestant Armenian associations established in Beirut Haigazian College (renamed Haigazian University in 1992), the only institution of higher learning in the Armenian diaspora. ${ }^{85}$ Armenian students who wished to pursue Armenology could also undertake their studies at Lebanon's two finest universities, the American University of Beirut and Université Saint-Joseph, each of which boasted a chair of Armenian studies. (The Université Saint-Joseph established its chair of Armenian studies in 1959,86 the same year Harvard became the first university in America to do likewise. ${ }^{87}$ ) Lebanon was also a center for religious education in both the Apostolic and Catholic Armenian communions. ApostolicArmenian ordinands came from all over the world to study in Antelias at the Cilician See's preeminent seminary. Likewise, aspiring Catholic Armenian clergy from throughout the diaspora came to Lebanon to receive instruction in the seminary in Bzoummar.

\section{Religion}

For Apostolic and Catholic Armenian laity all over the world, Lebanon is no less a spiritual lodestar. That Lebanon hosts the headquarters of the Holy See of Cilicia and the Armenian Catholic Patriarchate imparted to the country a unique significance in the Armenian diaspora. Apostolic Armenians in Lebanon, Syria, Iran, Iraq, Greece, Cyprus, Jordan, and many in the West are subject to the jurisdiction of the Holy See of Cilicia. During the Cold War, when many Apostolics looked upon the other great see of their church, that of Echmiadzin in Soviet Armenia, as obeisant to the communists, the Holy See of Cilicia in Lebanon assumed still more importance as the "uncorrupted" Armenian church. Consequently, the Cilician Catholicosate probably commanded the allegiance of the majority of Apostolics in the diaspora. ${ }^{88}$ Whereas Apostolic Armenians are divided between the Holy Sees of Cilicia and Echmiadzin, Armenian Catholics submit to one supreme patriarch. From his cathedra in Ashrafiyeh, Beirut, the patriarch exercises jurisdiction over all Armenian Catholic dioceses in the world. ${ }^{89}$

\footnotetext{
83 Adalian, 585.

84 Hewsen, 268.

${ }^{85}$ Adalian, 497.

86 Hewsen, 268. Globe, July 22, 2012 found-national-association-for-armenian-studies-andresearch/7nks5nT0aYSsMNu9aozPzM/story.html).

${ }^{88}$ Corbin, Griffith, and Rahhal, 408.

${ }^{89}$ Bedoyan, 121.
}

87 Stephanie M. Peters, “Manoog S. Young, Catalyst for Armenian Studies Programs,” Boston

(http://www.bostonglobe.com/metro/obituaries/2012/07/21/manoog-young-helped- 


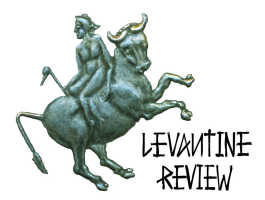

\section{Diversity}

Just as Lebanon's population, with its eighteen official sects, is the most variegated in the Middle East, so the country's Armenian community is the most religiously eclectic in the Armenian diaspora. ${ }^{90}$ Counting 80 percent Apostolic, 15 percent Catholic, and 5 percent Protestant, 91 the Lebanese Armenian population is proportionally far more religiously diverse than its counterpart in the modern Republic of Armenia. Lebanon's Catholic population, as noted, was at one time the largest in the diaspora, and Protestant Armenians, for their part, have garnered influence and visibility in Lebanon far beyond what their modest numbers would suggest. Religion is not the only element that accounts for the Lebanese Armenians' diversity. In politics, too, Lebanese Armenians are a multifarious lot. True, Dashnak was the hegemon of Lebanese Armenian politics from the late fifties until the last Lebanese parliamentary election, in 1972, before the civil war. But Ramkavar and Hunchak remained a part of the scene throughout. Indeed, so active were all three of these parties in Lebanon that they all chose to base their flagship headquarters there for a time. ${ }^{92}$ In this, Lebanon became for Armenian politics what it had been for Armenian Apostolics and Catholics worldwide: the hub of multinational Armenian institutions. Nor has Dashnak been able to retain the primacy it once wielded in Lebanese Armenian politics. The party has been in eclipse in Lebanon since 1992, while candidates from Hunchak and Ramkavar have been returned repeatedly to the Chamber of Deputies ever since. What is more, nonaffiliated Armenian deputies have won a plurality of mandates in every parliamentary election since 1992. It also bears noting that, though uncommon, Armenians have occasionally joined non-Armenian political parties and even ascended to leadership positions in them. Joseph Chader, a Catholic Armenian, was not only a former vicepresident of the Maronite Kataeb party, but also its first parliamentarian to serve in the Chamber of Deputies, and Karim Pakradouni, an Apostolic, won election as president of the party in 2001 .

No less varied are the origins of Lebanese Armenians. The result of the many Armenian influxes to Lebanon is that the Lebanese Armenian community has come to resemble a palimpsest that bears traces of each wave of refugees that has settled in the land, from the Catholic refugees who came in the late seventeenth century to the Aleppine refugees who are taking sanctuary in Lebanon today. Until the 1880s, it will be recalled, Lebanese Armenians were overwhelmingly Catholic, they or their ancestors having fled Apostolic persecution in the Armenian homeland. Thereafter, the complexion of the Lebanese Armenian community changed dramatically. Masses of largely Apostolic Armenian refugees from the Hamidian Massacres began arriving in Lebanon and setting up their own sectarian institutions. After the genocide, Armenians from Cilicia, from the six vilayets of Ottoman Armenia, and from elsewhere in the empire, flooded Lebanon. Lebanon now played host to

90 Schahgaldian, Political Integration, 75.

91 Schahgaldian, Political Integration, 75.

92 Bedoyan, 124. 


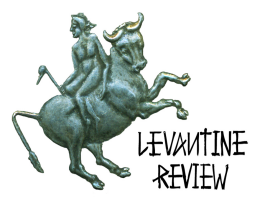

an extraordinary congeries of Armenians. A special curiosity was the new linguistic landscape of the Lebanese Armenian community. The veteran Catholic Armenians spoke mainly the Lebanese dialect, or French. The Hamidian refugees and their descendants mostly spoke Armenian. The Cilician Armenians and the Armenians from Ottoman provinces outside historic Armenia overwhelmingly spoke Turkish and often had no knowledge of Armenian. In due course, the Turkish Armenians or their children would learn Armenian, but the Catholics, long accustomed to French and the dialectal variant of Lebanon, generally continued to neglect Armenian in favor of these languages. In the twenties, refugees from Soviet Armenia, Syria, and, at the end of decade, Turkey, settled in Lebanon and added further variety to the country's already farraginous Armenian population. By the early thirties, the Lebanese Armenian community was a crucible in which coexisted Armenians of three different faiths, of four different language groups (to say nothing of the dialectal differences), and of numberless different origins. Moreover, in the refugee camps there lived side by side former peasants, urbanites, villagers, mountaineers, elites-Armenians of every variety of background-all brought together by the first genocide of the twentieth century.

A further influx of Armenian refugees settled in Lebanon a few years later, but unlike before, these were homogenous, coming as they did from the same province. In the late thirties, thousands of Armenian refugees uprooted themselves from the Sanjak of Alexandretta (Iskenderun or Hatay) and fled to Lebanon, among other places. As Turkey stood poised to annex the Sanjak, which had been an autonomous province within the French Mandate's États du Levant since 1921, the Armenians there feared a reprise of the Turkish atrocities that had ended only a few years earlier. The French Mandatory authorities in Lebanon meted out to the newcomers plots of farmland in the Beqaa Valley. It was there in the early forties that the Armenian refugees built atop a marsh (rather as they had in Bourj Hammoud) an entirely Armenian hamlet. Anjar, for so this new village was named, quickly grew into a town of several thousand. Thanks in part to the entreaties of Maronite notables, ${ }^{93}$ the French Mandatory authorities extended citizenship en masse to all the Armenians of the village. ${ }^{94}$

Armenian refugees continued to throng into Lebanon in the years that followed. Palestinian Armenian refugees from the First Arab-Israeli War and Syrian Armenians fleeing repression and instability both sheltered in Lebanon. ${ }^{95}$ With the possible exception of the Republic of Armenia, there can scarcely have been another country in modern times that has attracted and absorbed so many Armenians of such disparate backgrounds.

93 Schahgaldian, Political Integration, 61.

94 Zaven Messerlian, Armenian Representation in the Lebanese Parliament (MA Thesis, American University of Beirut, 1963), 14.

${ }^{95}$ Michael W. Suleiman, Political Parties in Lebanon: The Challenge of a Fragmented Political Culture (Ithaca: Cornell University Press, 1967), 186. 


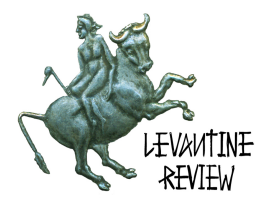

\section{ARMENIANS AS A DISTINCTIVE COMMUNITY IN LEBANON}

Vis-à-vis the rest of the Lebanese body politic, the Lebanese Armenian community is likewise distinctive, singular even. In Lebanon's fabled "mosaic of minorities," Armenians stand out as the country's only community that is neither Arab nor Muslim nor principally Arabic-speaking. ${ }^{96}$ In religion, Lebanese Armenians, like other Lebanese sects, profess their own particularist faiths, but the Apostolics differ in being the country's most secularized group. ${ }^{97}$

More substantive differences also mark Lebanese Armenians off from Lebanon's other sects. Whereas influential clans or clergy have traditionally dominated Lebanon's other groups, political parties have exercised leadership over Lebanese Armenians since the modern Lebanese Armenian community took form. This difference arose organically from the two contrasting histories of the Armenians and the rest of the Lebanese population. Until the second half of the nineteenth century, the two most powerful elements among the Armenians of the Ottoman Empire were the Apostolic church and the haute bourgeoisie, the so-called "amiras," (Ottoman functionaries, financiers, business barons, and other grandees.) These two apolitical and reactionary groups collaborated and even partly fused. But as the century advanced, their duopoly began to crumble. The emergence of an Armenian middle class, the stirrings of Armenian nationalism, and the institutional reforms of the Tanzimat era all conspired to erode their power. In the 1880s, amid this decline, Armenian political parties espousing nationalism, socialism, and anti-clericalism began germinating. In due course, these new parties, particularly Dashnak, assumed an ever more prominent role in Armenian life. On the strength of its reputation as the tribune of the Armenians and the vanguard of Armenian nationalism, Dashnak won a substantial following. The Armenian Church, for its part, abandoned its political quietism and belatedly made its terms with Armenian nationalism but remained marginal in the nationalists' struggle. So with the amiras gone and the church overtaken, the Armenian political parties were increasingly able to assert themselves as leaders of their people.

The case of communal leadership in Lebanon was otherwise. In Lebanon, power was for centuries vested in two elements: the clergy and, even more so, the notables. The latter were dynastic feudal chieftains who controlled hereditary tax farms. In their semiautonomous fiefs, they administered justice, kept the peace, and levied and collected taxes. Certain wealthy clans among Lebanon's major sects established themselves as the leading feudal families in the country. So entrenched was their power that it even outlived feudalism itself in Mount Lebanon, which was abolished in 1861 with the creation of the Mutasarrafiya. They still had their prodigious landholdings, but many of their members now took up senior positions in the administration of the Mutasarrafiya and so retained

${ }^{96}$ Arguably, Lebanon's small communities of Assyrians and Chaldeans (some of whom speak Eastern neo-Aramaic vernaculars) could be said to conform to this profile. ${ }_{97}$ Corbin, Griffith, and Rahhal, 406. 


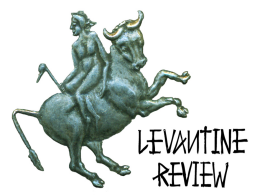

their influence. Meanwhile, in the burgeoning coastal towns like Beirut and Sidon, scores of magnates had arisen who had won their fortunes in banking and commerce. This urban aristocracy, together with the far more numerous clans of former feudal chieftains, now formed a very a wealthy and influential class. The clergy, for its part, exercised varying degrees of leverage among Lebanon's sects. They were most influential among the Maronites and least among the Druze. It was indeed the Maronite Church in the person of Patriarch Elias Howayek whose lobbying at the Paris Peace Conference helped to bring about the creation of the Lebanese state in 1920. But while the new Lebanon, with its separation between civil and religious authority and secular institutions of power, undermined the clergy, it offered the powerful clans of notables (the former feudal lords and urban magnates) the opportunity to wield political power. In other words, the new Lebanese order relegated clerical authority to the spiritual realm while expanding mercantile and former feudal influence into the political realm. To be sure, the clergy remained influential, but theirs was mostly a soft power. The notables, on the other hand, became hegemonic. After they entered politics they became known as zu'ama, or "big men," and throughout the state's history, particularly until the Second Civil War, they have been ascendant. Illustrative is the datum that thirty-five percent of the seats in the Chamber of Deputies were monopolized by six families until 1972,98 after which year another parliamentary election was not held for two decades. As a result of zu'ama supremacy, political parties (as distinct from parliamentary blocs) arose comparatively late in Lebanon. Moreover, when parties did emerge, they were mostly organizational arms of the zu'ama and their clans.

Whereas the zu'ama and their political formations predominated among the rest of Lebanon, political parties were the masters of Armenian life in the country. Formal political organization among Armenians, which, as noted, dates from the 1880s, began around a half-century earlier than it did among the Lebanese. So when Dashnak began recruiting and ministering to the needs of the Armenian refugees in Lebanon in the 1920s, it was already a seasoned political party. So, too, was Hunchak. With no competition from any other Armenian element (there was no traditional Armenian leadership or oligarchic clans as there was in the rest of Lebanon, $)^{99}$ the three Armenian political parties expanded their constituencies readily. Their only competition was each other, and because Ramakavar was small, new, and allied with Hunchak, this was really a two-way contest. What is more, after many Lebanese Hunchak and Ramkavar partisans emigrated in the forties as part of the repatriation program to Soviet Armenia, and, most especially, after the Dashnak's candidate became Cilician patriarch in 1956, the Dashnak party sealed its position as the unchallengeable lord of Armenian politics in Lebanon. The Dashnak was thus able to achieve the leadership in Lebanon that it coveted and was barred from exercising in Soviet Armenia.

98 Kais M. Firro, Inventing Lebanon: Nationalism and the State under the Mandate (London: I.B. Tauris, 2003), 97.

99 Bedoyan, 124. 


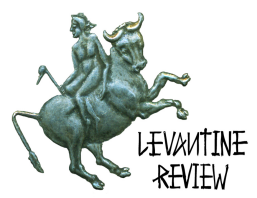

Lebanese Armenians were the only community in Lebanon in whose lives political parties were so influential. True, the Armenians had no zu'ama, so it was natural that parties should have assumed the role in their community that the $z u^{\prime}$ 'ama played among other Lebanese, but the degree to which the Armenian parties, especially Dashnak, impinged on the lives of Lebanese Armenians was extraordinary. The Armenian parties in Lebanon were far more than just political outfits. One's party affiliation might well have influenced his employment, schooling, place of residence, and even fraternizing. As Schahgaldian observed, "the parties effectively controlled most religious, educational, administrative, sportive, and professional structures of the community as well." 100 So in leadership, in political organization, and in the longevity and influence of their political parties, Armenians stood as outliers in the Lebanese body politic.

So, too, did the Armenians differ from the rest of the Lebanese in their involvement in Lebanese politics. From the earliest years of the Lebanese Republic to the end of the Second Civil War, contrary visions of Lebanon and its place in the world have riven Lebanese society: Should Lebanon be a sovereign state, or should it be annexed to Syria? Should it be aligned with the West or with the Arab world? Should it uphold confessionalism or should it abolish it? Should it stay out of the Arab-Israeli conflict or should it support the Palestinians and the regional Arab countries in their fight against the Jewish state? For most of Lebanon's history, these and other existential questions were both determinants of political affiliation and causes of internecine war. For a Lebanese faction to respond to these questions was to range itself on one side of the political fault line. The Armenians, though, were the only group in Lebanon that declined to stake out a position either way in answer to these questions.

Triangulation, neutrality, and consensus positions were the Armenians' refuges. When it came to the divisive and volatile questions of Lebanese identity, it was impossible to embrace a position without antagonizing or provoking the opponents of that position. The Armenians accordingly decided that their involvement in Lebanese politics would largely be limited to advancing their own particularist interests. This was not to say Lebanese Armenians were privately as agnostic as their representatives appeared publicly-the Armenians mostly sympathized with other Lebanese Christians-but at the official level they were resolved to detaching themselves from the nation's bitter political quarrels. But the Armenians' mugwumpery was not without its perils either. If espousing a certain position could alienate the opponents of that position, then omitting to espouse a position could similarly alienate the supporters of that position. So it was during the Second Lebanese Civil War. Though the Armenians sympathized with the status quo forces-those who were fighting to uphold confessionalism and Christian privilege-the three Armenian parties agreed at the outset of the war to hew to a posture of "positive neutrality"

100 Schahgaldian, Political Integration, 61. 


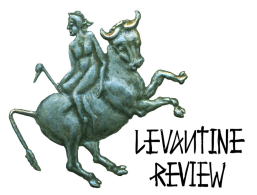

throughout. To parry accusations of disloyalty, the preeminent parliamentarian of the Lebanese Armenians, Khachik Babikian, argued that the Armenians' neutral stance proceeded from devotion, not indifference, to Lebanon. ${ }^{101}$

This explanation scarcely commended itself to Bashir Gemayel, the chief exponent of the status quo and the leader of the Lebanese Forces-a consortium of Christian militias. Gemayel charged the Armenians with ingratitude and even betrayal. In a vituperative speech, he thundered that "we opened our hearts to them...we never made them feel as foreigners in Lebanon...but these actions were not mutual...when time came to pay a blood tax" the Armenians shirked. ${ }^{102}$ Feeling themselves aggrieved, some of the militias in the Lebanese forces attacked the Armenians, ${ }^{103}$ first, in October 1978, then, in September 1979.104 Thereafter, these disgruntled Christian militants relented and accepted Armenian neutrality. For the balance of the war, the Armenians remained neutral but maneuvered gingerly between the two sides. Typical of the Armenians' funambulism was a series of moves the community took in 1986. That year Khatchik Babikian endorsed a political statement promulgated by the Lebanese Forces. ${ }^{105}$ In reprisal for this perceived partisanship, Muslims killed four Armenians in West Beirut. ${ }^{106}$ The Armenians then made an overture to the Muslims and assented to the definition of Lebanon as an "Arab country," a formulation resisted by the Christian status quo forces. ${ }^{107}$

The Armenians have continued their distinctive balancing act in Lebanon up to the present day. ${ }^{108}$ More recently, their self-preservation-cum-political pragmatism has brought Dashnak into the March 8 coalition that includes Hezbollah, the Armenians having won a

101 Asbed Kotchikian, "Between (Home)land and (Host)land: Lebanese Armenians and the Republic of Armenia," in Armenians of Lebanon: From Past Princesses and Refugees to Present-Day Community, ed. Aida Boudjikanian (Beirut: Haigazian University \& Armenian Heritage Press, 2009), 471.

102 Rani Geha, Words from Bashir: Understanding the Mind of Lebanese Forces Founder Bashir Gemayel from his Speeches (Lexington, 2010), 22-23.

103 The Armenians were not the only target of Bashir Gemayel's aggression. The Lebanese Forces moved against Tony Franjiyeh's Marada militia in 1978 and Dany Chamoun's Tigers militia in 1980.

104 Migliorino, Reconstructing Armenia in Lebanon and Syria, 153.

105 Avsharian, 396.

106 Hala Jaber, "Moslem Terrorist Group Promises to Free Two Christian Hostages," Associated Press, June 17, 1986 http://www.apnewsarchive.com/1986/Moslem-TerroristGroups-Promises-To-Free-Two-Christian-Hostages/id-

f5d6687f97e84e54a903ba0b0b95d53e

107 Avsharian, 395.

108 Lebanese Druze are also known for subordinating ideology to pragmatism. But though the Druze, like the Armenians, might be given to expediency and political deal-making, they almost never refrain from taking positions firmly, never mind whether they hold to them. 


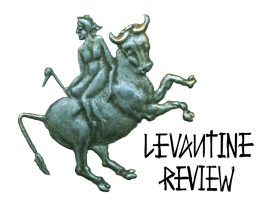

better deal from them. That a party that espouses secularism, nationalism, and socialism should be a partner with Islamists testifies to the Armenians' expediency more vividly than anything else. When Hovig Mekhitarian, the current chairman of Dashnak was asked to account for this improbable partnership, he answered with a formulation that could very easily serve as the political credo of Armenians in Lebanon: "We are not with the opposition and not with the majority... we try to maintain links to all sides."109

\section{ARMENIANS AND OTHER REFUGEES IN LEBANON}

Distinctive as they are vis-à-vis indigenous Lebanese, Armenians differ even more sharply from the two other large refugee communities in Lebanon: the Palestinians and the Kurds. If the Lebanese Armenian experience has been a success story, its Palestinian analogue has been a tragedy. Kindred though the Palestinians are to many Lebanese in language, ethnicity, and religion, the Palestinian refugees in Lebanon have been completely frozen out of Lebanese society. In 1948, the Lebanese government settled the 100,000 Palestinians who poured into the country then in about a dozen refugee camps mostly outside of coastal cities. As with all other countries in the region save Jordan, Lebanon barred the refugees from integrating into society. The consensus among the Arab regimes was that the refugees were no more than squatters who would be repatriated after Israel's imminent destruction. Also, integrating, or worse, naturalizing the refugees, would be defeatist acquiescence in the existence of Israel. For Lebanon, though, there also figured a demographic consideration in this calculus. Lebanese Christians, whose onetime majority entitled them to a greater share of power than the country's Muslims, declined to enfranchise the overwhelmingly Muslim Palestinians in any way that might imperil their demographic edge and, in consequence, their political clout. The Palestinians were thus confined to the refugee camps. They were also subject to a number of other disabilities. They were barred from practicing certain occupations, from buying property, from receiving government benefits and so on. Of the Palestinians' plight Lebanon expert William Harris has said that "the Lebanese regime did its best to make life as uncomfortable as possible for the Palestinians." 110 After the Six-Day War, the Palestinians began staging raids into Israel from Lebanon and clashing with the Lebanese Army, which was intent on subduing the Palestinians and ending Israeli retaliation against Lebanon. In the fifteen-year civil war that followed, the Palestinians were one of the principal combatants and, depending on the narrative, the original provocateur. Today, the four hundred thousand Palestinians in Lebanon are scarcely more integrated into the country than when they or their forbears arrived in 1948. While a law was carried in the Chamber

\footnotetext{
109 Robert F. Worth, “In Lebanon's Patchwork, a Focus on Armenians' Political Might,” The New York Times, May 25, 2009 (http://www.nytimes.com/2009/05/26/world/middleeast/26armenians.html?_r=0). 110 William Harris, Faces of Lebanon: Sects, Wars, and Global Extensions (Princeton: Markus Wiener, 1997), 310.
} 


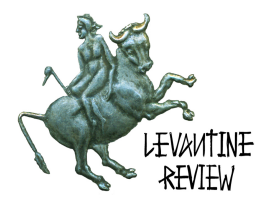

of Deputies in 2010 that modestly eased work restrictions on them, the Palestinians in Lebanon remain hemmed in 12 refugee camps and dependent on the UN for necessities.

The lot of Lebanese Kurds has been better, if hardly so. Kurdish refugees fleeing turmoil in Turkey began streaming into Lebanon after the First World War. A second influx, this one from Syria, followed in the 1960s, 111 after the Syrian government at a stroke divested more than 100,000 Kurds in al-Hasakah of their citizenship. ${ }^{112}$ The Kurds took up lodgings in the slums of Beirut and found menial employment. Their circumstances were reduced and their dwellings ramshackle. The Lebanese government ignored them altogether and refused them citizenship. As for autonomy and representation, because the Sunni Muslim Kurds differ from Lebanon's Sunni Arabs in ethnicity, not religion, the state declined to recognize the Kurds as a separate sect. The Kurds were consequently denied the communal autonomy and political representation enjoyed by Lebanon's eighteen recognized sects. As the years passed, the Kurds' lot improved little, and they remained a marginalized, disdained community. Michael Gunter, the doyen of modern scholars of the Kurds, thus described their travail: "The Lebanese Kurds were often the victims of contempt, hatred, ridicule, and violence."113 Though there was scant reason for the Kurds to get entangled in the Second Lebanese Civil War, they nonetheless participated in the hostilities. The Kurds generally sided with and fought alongside the Druze, particularly Kamal Jumblatt's Progressive Socialist Party. ${ }^{114}$ They also joined the Nasserist Murabitun movement but felt slighted by the party for not being Arab. ${ }^{115}$ The fortunes of the Kurds rose modestly in 1994 when many of their number were awarded citizenship along with tens of thousands of Syrians and others. This gesture notwithstanding, Lebanese Kurds, as McDowall notes, "still feel relatively friendless. They have found few in Lebanon really willing to fight their corner, or represent their interests."116

As is plain from the foregoing, differences between the Lebanese Armenian experience and the Lebanese Palestinian and Lebanese Kurdish experience abound. Whereas Armenians had fully integrated into Lebanese society three decades after most of them arrived in Lebanon, Lebanese Kurds and Palestinians remain marginalized, disenfranchised peoples, detached from Lebanese society in sentiment and in practice. The Armenians, moreover, have enjoyed prosperity, political representation, and communal autonomy, while the Palestinians and Kurds have languished as an underclass, abandoned to political orphanhood. The Armenians and these two other refugee communities differ further in their relations with the rest of the Lebanese population. Amity and mutual respect have generally been the touchstones of the Armenians' relations with the native Lebanese. The

111 David McDowall, A Modern History of the Kurds (New York: I.B. Tauris, 2004), 485.

112 Kerim Yildiz, The Kurds in Syria: The Forgotten People (London: Pluto, 2005), 34.

113 Michael M. Gunter, The A to Z of the Kurds (Lanham: Scarecrow, 2003), 126.

114 McDowall, 486.

115 Gunter, 486.

116 Gunter, 487. 


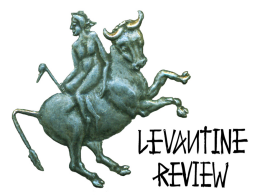

Maronites in particular have routinely shown hospitality to Armenian newcomers, from the relief they offered Armenian Catholic refugees in the late seventeenth century to their exertions on the Armenians' behalf in the 1920s and 1930s. So, too, has the Lebanese government supported the Armenians. Christian notables and the French Mandatory government sought to facilitate the Armenians' settlement in the 1920s, and Bishara alKhoury's administration between 1946 and 1949 provided assistance to Lebanese and Syrian Armenians who wished to immigrate to Armenia during Soviet Armenia's international repatriation campaign of those years. ${ }^{117}$ Moreover, the Lebanese government has twice awarded citizenship to Armenians collectively, first, in 1924 and later, in 1939. In the latter case, the Maronites interceded with the Mandatory government to this end. 118 Palestinians and Kurds, per contra, have often met with hostility and ostracism from the Lebanese population and discrimination from the Lebanese government. The Palestinians have been denied citizenship, confined to refugee camps, and refused many of the rights and privileges enjoyed by the native Lebanese. And even though the Kurds were permitted to apply for citizenship in 1994, forty percent of them have yet to be naturalized.119 Still another difference between the Armenians and the Palestinians and the Kurds has been Armenian neutrality in the Second Lebanese Civil War in contrast to Palestinian and Kurdish participation. Whereas the Armenians took pains to espouse neutrality, the Palestinians and the Kurds to a lesser extent were belligerents and partisans of the mostly Muslim opponents of the status quo. Consequently, Bourj Hammoud was relatively secure during the war, ${ }^{120}$ and the Armenians probably incurred the fewest fatalities of all Lebanon's groups, while the Palestinians and the Kurds suffered more than anyone else in the population. ${ }^{121}$

\section{CONCLUSION}

Lebanon, for many Armenians, is referred to as "our second homeland" (yergort hayrenik), ${ }^{122}$ and it is scarcely difficult to see why. As nowhere else in the regional diaspora, Lebanon has offered its Armenians the economic freedom to achieve prosperity, the political freedom to pursue their interests, and the communal autonomy to preserve their identity. These freedoms and the efflorescence they have enabled-to say nothing of Lebanon's singularity as the scene of unique Armenian ecclesiastical and cultural institutions-have made Lebanon a distinctive part of the Armenian diaspora. Lebanese Armenians' social integration, too, marks their community off as distinctive. Of the other countries in the region only Iran has been looked upon by Armenians as a "second homeland." But ethnic Persians have not often exhibited the same warmth toward Iranian

\footnotetext{
117 Nalbantian, 20.

118 Schahgaldian, Political Integration, 61.

119 McDowall, 488.

120 Migliorino, 171.

121 McDowall, 487.

122 Kotchikian, 463.
} 


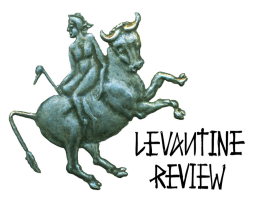

Armenians that Iranian Armenians have felt toward Iran. Cosroe Chaqueri accordingly observes that "Armenian-Iranians, who have lived in Iran as a Christian community practically since Iran was founded as a keshvar (nation-state) by the Achaemenids, have never been accepted as fully Iranian [...] their community was always mentioned along with groups of foreigners." 123 In Lebanon, it has been otherwise. No less a figure than Camille Chamoun, the Lebanese president from 1952 to 1958, thus addressed Lebanese Armenians during his incumbency: "You should consider yourself in your own home, since it is without exaggeration when I say Lebanon is a second Armenia." 124 Also in the fifties, Raymond Eddé, another of Lebanon's leading statesmen in the twentieth century, spoke of "Armenians of the Lebanese family."125 In fact, so comfortable did Armenians feel in Lebanon that many of those who left Lebanon for Soviet Armenia in the forties under the USSR's Armenian repatriation drive actually returned to live in Lebanon. ${ }^{126}$ Just as Lebanese Armenians are distinctive in the Armenian diaspora, so, too, are they distinctive as a community in Lebanon. Not only do Armenians differ from all other Lebanese in language, ethnicity, and confession, their political leadership and their rigorous avoidance of conflict further distinguish them. Still more striking are the divergences in the experiences of Armenians and Lebanon's other refugees, Palestinians and Kurds.

The Second Lebanese Civil War convulsed the Lebanese Armenian community just as it did the rest of the country. But while the insecurity and economic dislocation of the war caused Lebanese Armenians to lose much of their number to emigration, the distinctive features and manifold successes of the community yet remain.

* Scott Abramson is a Ph.D candidate in the Department of Near Eastern Languages and Cultures at UCLA. His research and doctoral work focus on modern Levantine history.

${ }^{123}$ Cosroe Chaqueri, "The Armenian-Iranian Intelligentsia and Non-Armenian-Iranian Elites in Modern Times: Reciprocal Outlooks," in The Armenians of Iran, ed. Cosroe Chaqueri (Cambridge: Harvard University Press, 1998), 128-129.

124 Nalbantian, 121.

125 Ibid., 295.

126 Corbin, Griffith, and Rahhal, 398. 


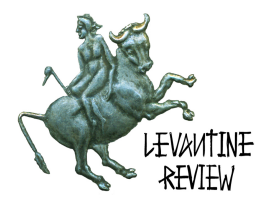

\section{BIBLIOGRAPHY}

Adalian, R. P. (2010). Historical Dictionary of Armenia. Lanham: Scarecrow Press. Afary, J. (1996). The Iranian Constitutional Revolution, 1906-1911. New York: Columbia University Press.

Avsharian, R. (2009). The Ta'ef Agreement and the Lebanese-Armenians. In A. Boudjikanian (Ed.), Armenians of Lebanon: From Past Princesses and Refugees to PresentDay Community (pp. 387-408). Beirut: Haigazian University Press.

Aynilian, G. H. (2012, January 20). Armenian Deputies in Lebanon (1929-2009). Retrieved December 10, 2012, from Keghart : http://www.keghart.com/Aynilian-Deputies Balakian, P. (2003). The Burning Tigris: The Armenian Genocide and America's Response. New York: HarperCollins.

Bedoyan, H. (1979). The Social, Political, and Religious Structure of the Armenian Community in Lebanon. The Armenian Review, 32 (2), 119-130.

Bouldoukian, M. (1979). Armenian Business in Lebanon. The Armenian Review , 32 (2), 131133.

Bournoutian, G. A. (2006). A Concise History of the Armenian People. Costa Mesa: Mazda. Chaqueri, C. (1998). The Armenian-Iranian Intelligentsia and Non-Armenian-Iranian Elites in Modern Times: Reciprocal Outlooks. In C. Chaqueri (Ed.), The Armenians of Iran (pp. 119161). Cambridge: Harvard University Press.

Corbin, H., Griffith, K., \& Assad, R. (1975). Observations on the Armenians in Lebanon Made in 1970-1973. The Armenian Review , 28 (4), 391-409.

Dekmejian, R. H. (2004). The Armenian Diaspora. In R. G. Hovannisian (Ed.), Armenian People from Ancient to Modern Times 2 (pp. 413-443). New York: St. Martin's.

Der Ghoukassian, K. (2009). Lebanon in My Mind. The Civil War and the Centrality of the Lebanese-Armenian Community in the Making of the Armenia Diaspora Nationalism. In A. Boudjikanian (Ed.), Armenians of Lebanon: From Past Princesses and Refugees to PresentDay Community (pp. 411-429). Beirut: Haigazian University.

Der-Karabetian, A. H. (1981). Image and Self-Image of Armenians in Lebanon: A Psychosocial Perspective. In R. G. Hovannisian (Ed.), The Armenian Image in History and Literature (pp. 241-249). Malibu: Undena.

Der-Karabetian, A., \& Oshagan, E. (1977). Ethnic Orientation of Armenians in Lebanon. The Armenian Review , 30 (2), 164-175.

Der-Karabetian, A., \& Proudian-Der-Karabetian, A. (1984). Ethnicity and Civil War: The Lebanese-Armenian Case.

Firro, K. M. (2003). Inventing Lebanon: Nationalism and the State Under the Mandate. London: I.B. Tauris.

Geha, R. (2010). Words from Bashir: Understanding the Mind of Lebanese Forces Founder Bashir Gemayel from his Speeches. Lexington.

Gunter, M. M. (2003). The A to $Z$ of the Kurds. Lanham: Scarecrow. 


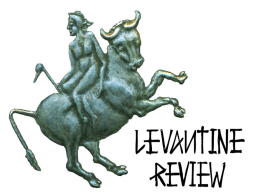

Harris, W. (1997). Faces of Lebanon: Sects, Wars, and Global Extensions. Princeton: Markus Wiener.

Hewsen, R. H. (2001). Armenia: A Historical Atlas. Chicago: University of Chicago Press. Hirst, D. (2010). Beware of Small States: Lebanon, Battleground of the Middle East. New York: Nation.

Hitti, P. K. (1967). Lebanon in History: From the Earliest Times to the Present. London: Macmillan.

Hovannisian, G. K. (2010). Family of Shadows: A Century of Murder, Memory, and the Armenian American Dream. New York: Harper Collins.

Jaber, H. (1986, June 17). Moslem Terrorist Group Promises to Free Two Christian Hostages. Retrieved December 14, 2012, from http://www.apnewsarchive.com/1986/MoslemTerrorist-Groups-Promises-To-Free-Two-Christian-Hostages/idf5d6687f97e84e54a903ba0b0b95d53e

Kaiser, H. (2009). The Armenians in Lebanon during the Armenian Genocide. In A. Boudjikanian (Ed.), Armenians of Lebanon: From Past Princesses and Refugees to PresentDay Community (pp. 31-56). Beirut: Haigazian University.

Kotchikian, A. (2009). Between (Home)land and (Host)land: Lebanese-Armenians and the Republic of Armenia. In A. Boudjikanian (Ed.), Armenians of Lebanon: From Past Princesses and Refugees to Present-Day Community (pp. 463-476). Beirut: Haigazian University. McDowall, D. (2004). A Modern History of the Kurds. New York: I.B. Tauris.

Messerlian, Z. (1963). Armenian Representation in the Lebanese Parliament. MA Thesis, American University of Beirut, Beirut.

Migliorino, N. (2006). Kulna Suriyyin? The Armenian Community and the State in Contemporary Syria. Revue des Mondes Musulmans et de la Mediterranee , 115-116. Migliorino, N. (2008). Reconstructing Armenia in Lebanon and Syria: Ethno-Cultural Diversity and the State in the Aftermath of a Refugee Crisis. New York: Berghahn. Migliorino, N. (2009). The Lebanese System and Armenian Cultural Diversity between Yesterday, Today, and Tomorrow: Opportunities and Limits. In Armenians of Lebanon: From Past Princesses and Refugees to Present-Day Community (pp. 479-492). Beirut: Haigazian University.

Nalbantian, T. (2011). Fashioning Armenians in Lebanon, 1946-1958. Ph.D. Dissertation, Columbia University, New York.

Payaslian, S. (2007). The History of Armenia. New York: Palgrave Macmillan.

Peters, S. M. (2012, July 22). Manoog S. Young; Helped Found the National Association for Armenian Studies and Research-Obituaries. Retrieved December 12, 2012, from Manoog S. Young, Catalyst for Armenian Studies Programs:

http://www.bostonglobe.com/metro/obituaries/2012/07/21/manoog-young-helpedfound-national-association-for-armenian-studies-and-

research/7nks5nT0aYSsMNu9aozPzM/story.html

Price, M. (2005). Iran's Diverse Peoples: A Reference Sourcebook. Santa Barbara: ABC-Clio. Rubin, B. (2007). The Truth About Syria. New York: Palgrave.

Sanasarian, E. (2000). Religious Minorities in Iran. Cambridge: Cambridge University Press. 


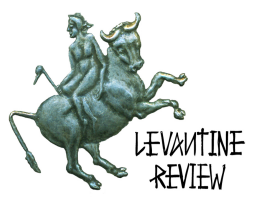

Sanjian, A. K. (1965). The Armenian Communities in Syria under Ottoman Dominion. Cambridge: Harvard University Press .

Schahgaldian, N. B. (1983). Ethnicity and Political Development in the Lebanese-Armenian Community, 1925-1979. The Armenian Review , 36 (1), 46-61.

Schahgaldian, N. B. (1979). The Political Integration of an Immigrant Community into a Composite Society: The Armenians in Lebanon, 1920-1974. Columbia University. New York.

Suleiman, M. W. (1967). Political Parties in Lebanon: The Challenge of a Fragmented Political Culture. Ithaca: Cornell University Press.

Tachjian, V. (2009). The Permanent Settlement of Armenian Refugees in Lebanon in the Years 1920 and 1930. In A. Boudjikanian (Ed.), Armenians of Lebanon: From Past Princesses and Refugees to Present-Day Community (p. 75). Beirut: Haigazian University.

Worth, R. F. (2009, May 25). In Lebanon's Patchwork, a Focus on Armenians' Political Might. Retrieved December 14, 2012, from

http://www.nytimes.com/2009/05/26/world/middleeast/26armenians.html?_r=0

Yildiz, K. (2005). The Kurds in Syria: The Forgotten People. London: Pluto. 